（72）反復負荷を受けるRC部林隅角部の耐力とダクティリティに関する实騟的研究

本州四国連絡橋公団正員松崎栘磨 建設省土木研究所正員栗林栄一 建設省土木研究新正員○萩原良二

\title{
1.まえがき
}

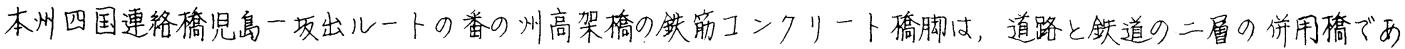
リ，図一トに示すように下段柱および上段柱からなっており、上段柱下端の隅角部においても地震力に対して必 要々する耐力ふらびにじん性を保有しマいることが要求される。ここでは、隅角部含含む上段柱の模型反復載荷 实驗によって得下铁筋コンクリ一ト部杖隅角部の耐力とじん性について報告する。

2 实 験 9 概要

建設省土木研究新的部科耐震強度实験施設去用い了以 下の特性を有する模型（図一2）をを对象に各々の荷重〜 变位の履歴特性ふどを得下。

模型A ……实橋の構造条件をできるだけ忠实に反映

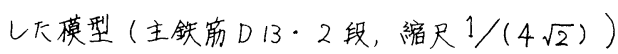

模型B……隅角部の八ンチの勍果を調べる下めの八

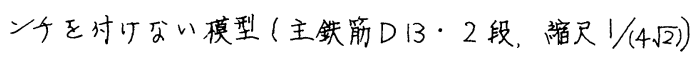
模型C ……主鉄筋下太径鉄筋を用い, 侧方筋を設置

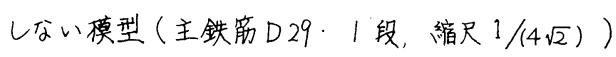

模型D……实樆の棈造条件をできるだけ忠实に反映 し、㜚尺を1/4として上部碃造の死有重反力下相当す る軸力も載荷しK模型（主鉄贺D B.3 段，樎尺 $1 / 4$ ) 荷重戴荷的道路橋上部榑造重心位置に正負交番水平力 載奇とし下。 少の場合，外 側主铁筋が降 犾点に達する まで(載荷点 変位ठ。まで) は荷重制御で 戴何し。吕れ 以降はঠ。の整 数倍の变位制 御で戴荷( く り返し回数 10 回) L下。

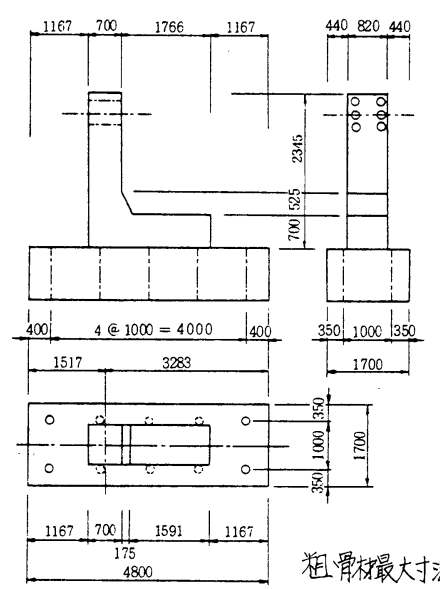

$1 /(4 \sqrt{2})$ 模型
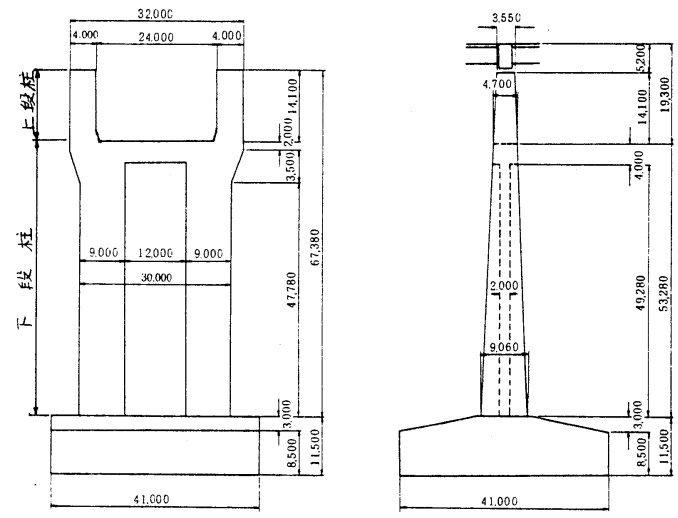

图一1 番の州高架橋一般四 力 


\section{3 实験結果}

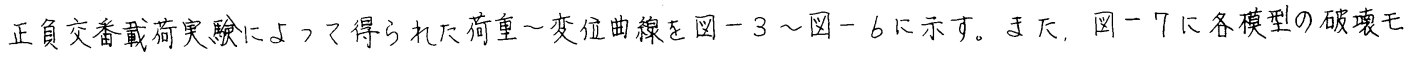

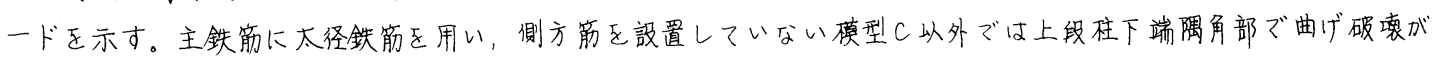
生じ下が，模型しでは上段柱上部でせん断破壊が生じ，他に比べて耐力ふらびにじん性が小さくなっている。こ れは側方筋がせん断抵抗に寄与している下めと考元られる。

实椅をできるだけ忠实にモデル化し下模型A（基本型）の荷重〜变位関係を見ると，最大荷重（终局荷重）は

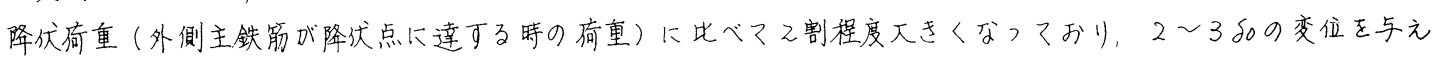
下時下荷重が最大となり，さらに变位が大きくなると 何重は次第下低下し，4５800变位を与元下時，降 仗有重程度下低下しマいる。ま下, 同一变位でくり返 し載荷し下時, 1回目の載荷で何重が影著下低下し， 2回目以降のくり返し載荷によつマ徐々下荷重が低下 しマいる。

降仗荷重までの荷重〜变位包路湶を四一8に示す。 主铁筋降伏時の䍑性は初期腩性下比ベマ1/3程度に低 下しマいる。ま下，ハンチの無い模型Bおよび側方筋 9無い模型しは基本型(模型 $A$ ) に比べマ/ 2 亿制程 度降份荷重が低下している。一方，軸力を考虑すると

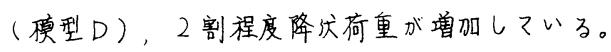

つぎに、ハンチの効果および軸力の影䇾について。

くリ返し載荷| 回目 $(n=1)$ および10回目 $(n=10)$ の荷重一变位包路線を描いマ检討し下（図一， 四一

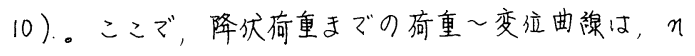
ニ1の場合は包络線を用い， $n=10$ 晹合はスケルト

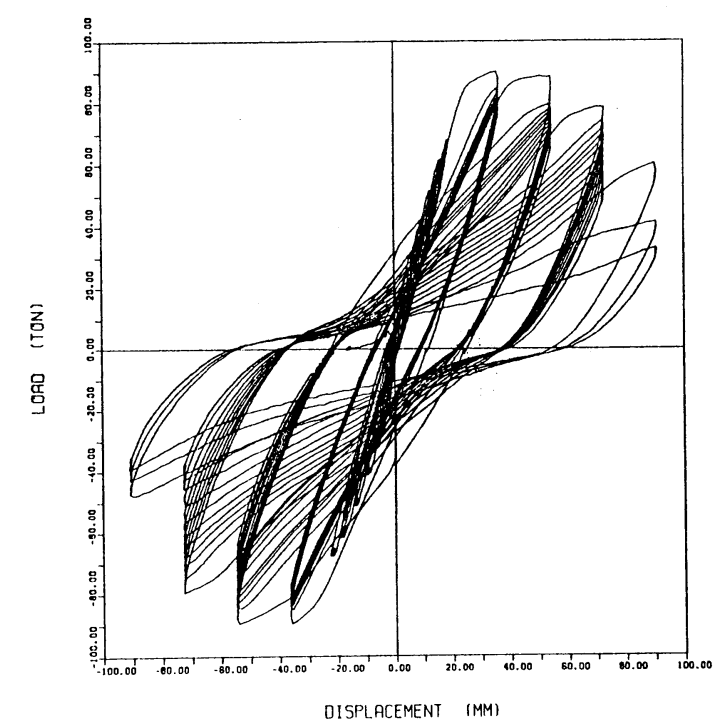

四一３模型A（基本型）９㢌重〜变位関係

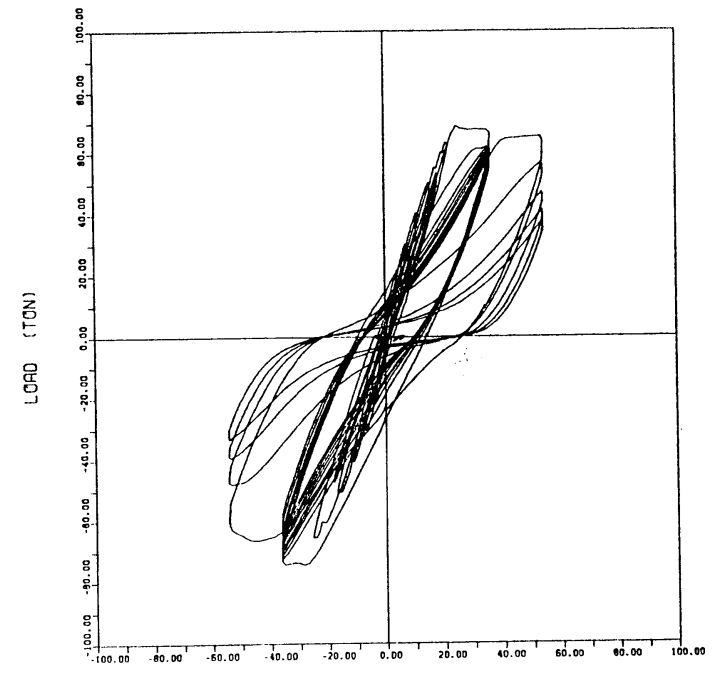

DISPLACEMENT (MM)

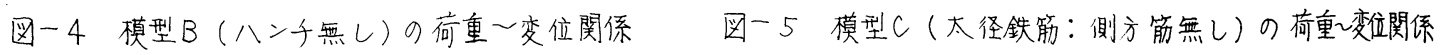


ンを用いマいる。八ンチを付 けることによって荷重が2〜 3割程度大きくな〉くおり, 負荷重（ハンチ测引張）に対 する㣠局变位おるびじん性率 以外の耐震性能は向上してお リ，八ンチを对けることの有 効性が確認さ扎下。軸力の影 響については, 軸力を載荷し 下晹合は軸力が無い場合下比 ベマじん性は低下するが耐荷 カは大きくなる。

图一片に、、降代時おるび 冬局时の抵抗モーメントの实 騟值と計算值の比較を行つ? いる。降代時では实騟值の方

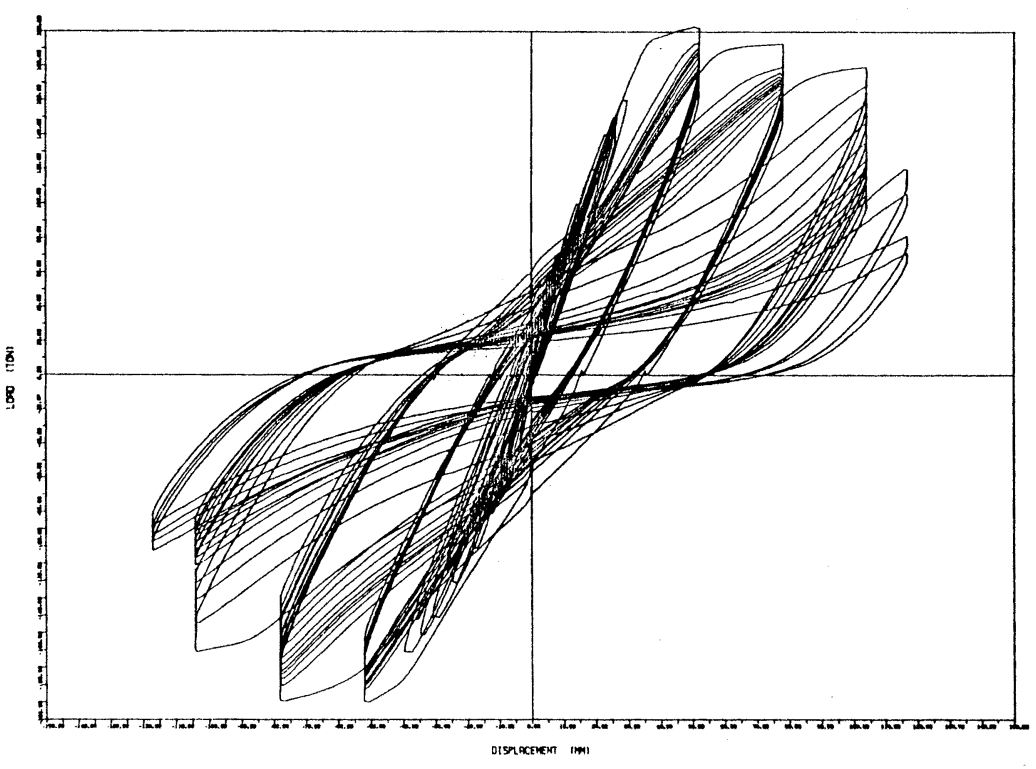

四一b模型D（1/4模型：軸力考虑）の倚重〜变位閔係

が大きめの值とふつマいるが、ひびわれ発生点と鉄筋のひずみ测定点が必ずしも一致しマいないことによるもの と考元られる。ま下，终局時では $n=19$ 場合は両者はよく对応しマいるが， $n=10$ 場合はくり返し載荷によ

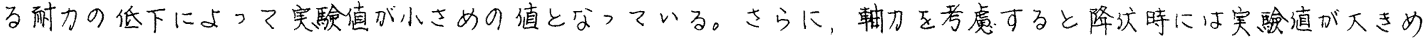
の値となり，终局時には小さめの值となるることなどがわかった。
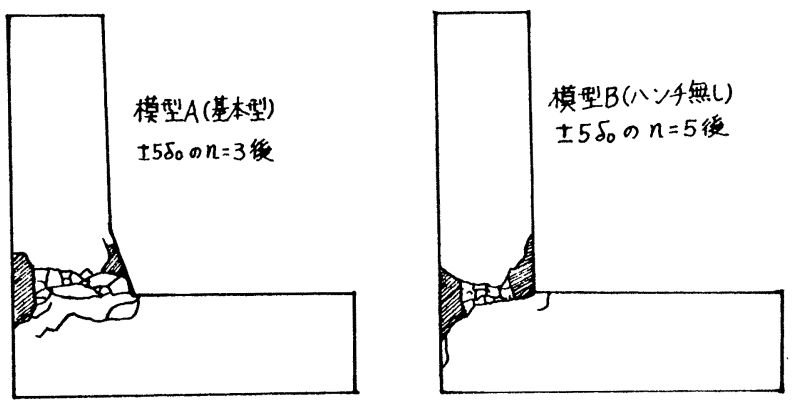

フミ゙に，道路橋示方書䙳震設計碥等下示さ れマいる方去で、コンクリートおるび鉄筋の応 力〜ひずみ関係を四一129るうに仮定して推定

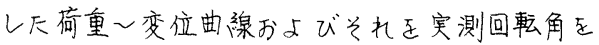
考慮しマ補正し下ものと实驗で得られ下荷重〜 变位曲線の比較を図一13に示しているが，上段 柱下端での回転角を考虑しない場合は降敒時の 变位は实騟值の $40 \sim 50 \%$ 程度であリ，回転を考
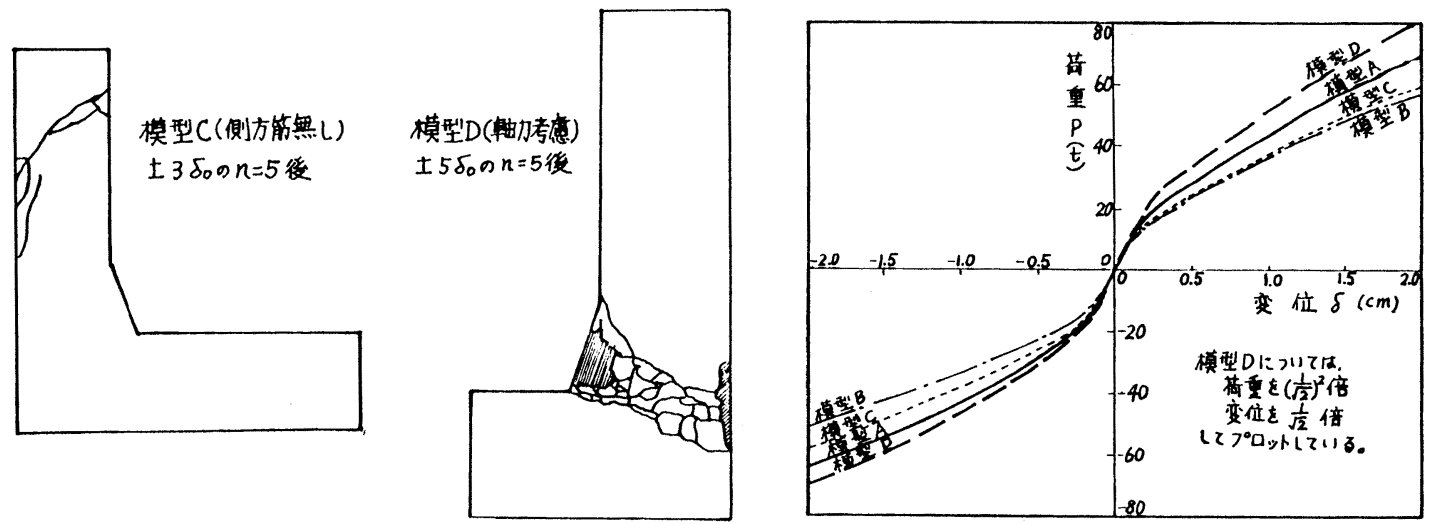

図一７破壞モ一

图一8主鉄筋降伏までク荷重〜变位包絡線 


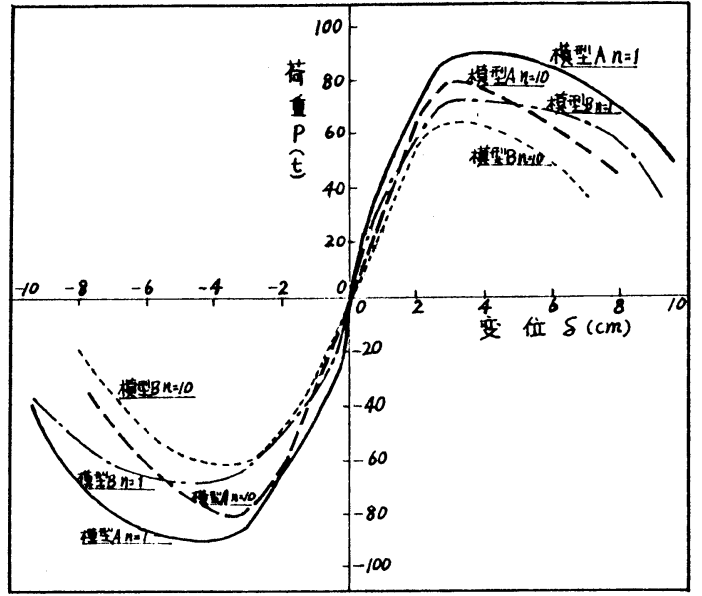

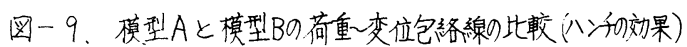

慮すると70〜80\%とふつマ实騟值に近似しマくる。し 下がっマンの回転角を考虍することが望ましい。

\section{4. あとがき}

今後この種の实験データの蓄積が必要である。

\section{参考文献}

建設省土不研究所：単一柱形式铁筋コン 7 リ一卜祜脚 の耐震設計法に関する研究，昭和

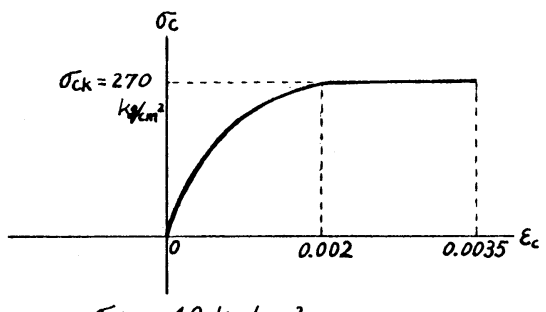

$\sigma_{c t}=40 \mathrm{~kg} / \mathrm{cm}^{2}$

$E_{c}=3.0 \times 10^{5} \mathrm{~kg} / \mathrm{cm}^{2}$

(a) コンクリート

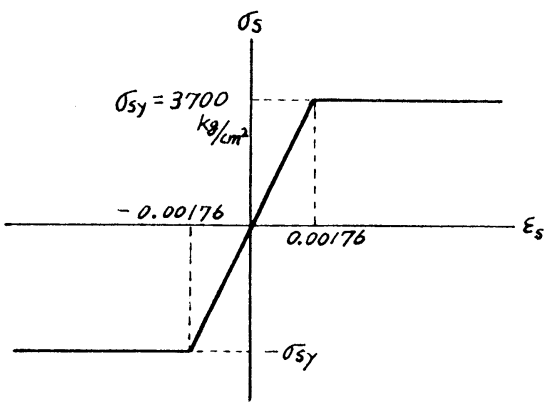

$E_{S}=2.1 \times 10^{6} \mathrm{~kg} / \mathrm{cm}^{2}$

(b) 鉄 筋

图一12棈造杖料》心力〜ひずみ関係つ仮定

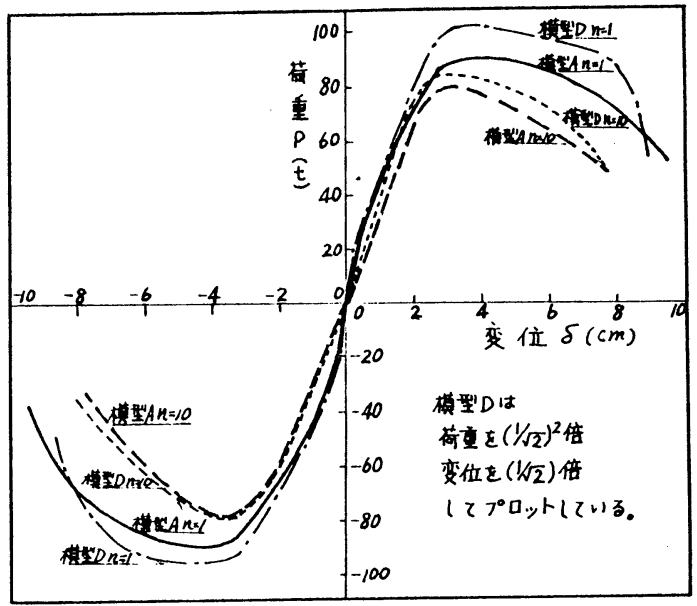

四一-10模型A 上模型D9荷重一变位包络缐の此較（軸加影響）

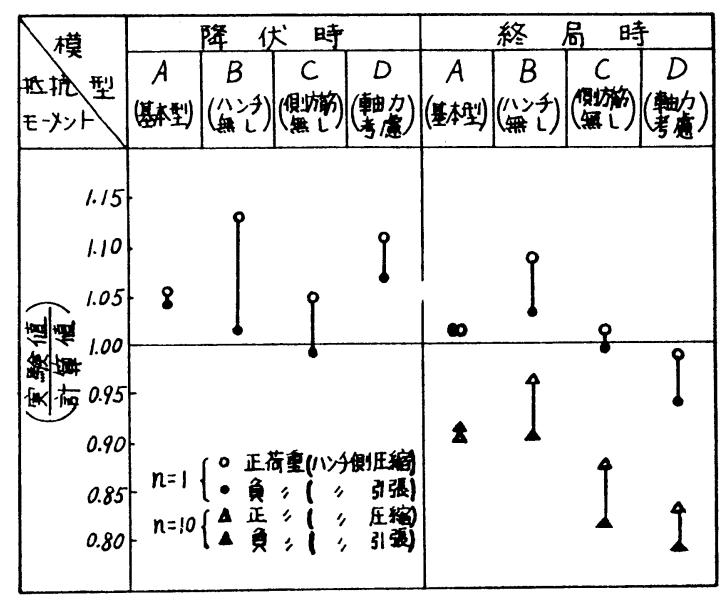

四一11隅角部の低抗モーメントの实驗值と計算値の比烄

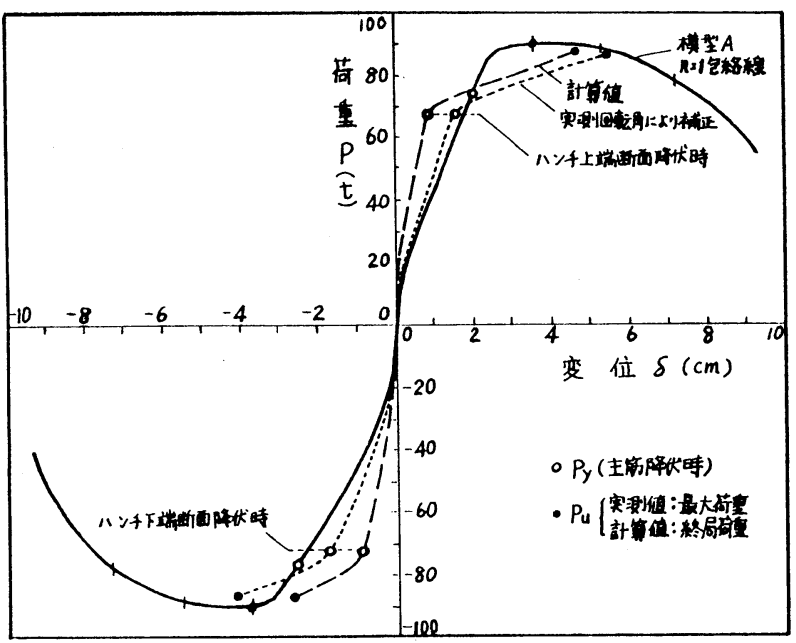

四一13 荷重つ变位曲線つ实娩值と計算值の比較 